\title{
INVESTIGATING CATALYTIC OXIDATION OF CYCLOHEXENE USING Fe(II) AND Co(II)PHTHALOCYANINE COMPLEXES
}

\author{
T.M. Sharanakumar ${ }^{1,2}$, N.Y. Praveen Kumar ${ }^{2}$, Mounesh $^{2}$, R. Vindhya ${ }^{3}$ \\ and K.R. Venugopal Reddy, \\ ${ }^{1}$ Department of Chemistry Ballari Institute of Technology and Management, Ballari-583104, \\ Karnataka (INDIA) \\ ${ }^{2}$ Department of Studies and Research in Chemistry, Vijayanagara Sri Krishnadevaraya \\ University, Ballari-583105, Karnataka (INDIA) \\ ${ }^{3}$ Department of Chemistry, Ballari Institute of Technology and Management, Ballari-583104, \\ Karnataka (INDIA) \\ Corresponding Author: venurashmi30@gmail.com
}

\begin{abstract}
The Carbutamide substituted Fe(II) phthalocyanine (CBTAFePc) and Co(II) phthalocyanine (CBTACoPc) complex was synthesized from tetra carboxylic acid $\mathrm{Fe}(\mathrm{II})$ phthalocyanine (FeTcPc) and tetra carboxylic acid Co(II) phthalocyanine (CoTcPc) with Carbutamide (CBTA) by linkage of amide has been developed. The macrocyclic molecules have high molecular weight and the molecule is completely soluble in Dimethylformamide and Dimethylsulfoxide. The synthesized complexes were confirmed by FTIR, Ultraviolet-Visible, PXRD, Mass, C,H,N and Thermo-gravimetric techniques. The catalytic activity of CBTAFePc and CBTAFePc were analyzed in the oxidation of Cyclohexene with various parameters like temperature, types of oxidants, oxidant/cat ratio, and subs/catalyst ratio affect the oxidation reactions were investigate the optimum conditions of catalysts. CBTAFePc shows excellent catalytic results on oxidation of Cyclohexene with the highest yield with good selectivity. The overall results show that the CBTAFePc complex exhibits an excellent catalyst compared with the CBTACoPc complex for investigation of the oxidation of Cyclohexene.
\end{abstract}

Keywords: CBTAFePc, CBTACoPc, Carbutamide, Cyclohexene and Gas Chromatography

RASĀYAN J. Chem., Vol. 14, No.3, 2021

\section{INTRODUCTION}

The industries and atmospheric pre-occupations need a common and more effective and low-cost catalyst. The degradation of pollutants was carried out by using an effective catalyst and the catalyst is a very important role in the synthesis of organic compounds and their derivatives. The oxidation of various molecules like alkenes, aromatics and alcohols are very important starting materials for the synthesis of bulk compounds for the production of chemicals in pharmaceuticals, cosmetics and polymerization of organic compounds. In the chemical reaction system, the selectivity of the catalyst was very important. ${ }^{1}$ In recent years the researcher mainly concentrates on the catalytic oxidation of Cyclohexene and its derivatives by using transition metal complexes as a catalyst. ${ }^{2}$

Carbutamide under the brand name glucidoral was used as the anti-diabetic drug to treat diabetes in France. Carbutamide belongs to the family of sulphonyl ureas and reduces the excess sugar in the blood by promoting the secretion of insulin. carbutamide promotes increased insulin secretion or it may potentiate the action of insulin. The carbutamide was useful for both acute and chronic treatments on both obese-hyperglycemic and their normal littermates. Metallo phthalocyanine (MPc) molecules exhibit good chemical and physical properties. They show high resistance to thermal and light radiations ${ }^{3}$, most of the phthalocyanine is insoluble in organic solvents. ${ }^{4}$ The macrocyclic compound of MPc formed by four isoindole groups connected with azomethine bridges was reported by Kadish K.M. et al. ${ }^{5-6}$ Physical, chemical and optical properties of MPc changes with central metal ions have been used in biomedical and industry $^{7-10}$. MPcs are important excellent materials used in scientific areas such as sensors, ${ }^{11-14}$ 
semiconductor ${ }^{15}$, dye-based solar cells, molecular electronics ${ }^{16-17}$, liquid crystals ${ }^{18}$, laser dyes ${ }^{19}$, nonlinear optics materials ${ }^{20}$, electro chromic ${ }^{21}$, photosensitizers for photodynamic therapy of cancer ${ }^{22-24}$, electrocatalytic $^{25}$ and catalytic activities. ${ }^{26}$

In this present work, CBTAFePc and CBTACoPc complex was synthesized from tetracarboxylic acid $\mathrm{Fe}$ (II) and $\mathrm{Co}$ (II) phthalocyanines with carbutamide (CBTA). The CBTACoPc has been characterized by FTIR, Ultraviolet-Visible, PXRD, Mass, C,H,N and Thermo-gravimetric techniques. A new method used for catalytic oxidation of Cyclohexene is reported for the first time. The catalytic activity (CA) of $\mathrm{CBTAFePc}$ and $\mathrm{CBTACoPc}$ were performed in the oxidation of Cyclohexene with various oxidants and parameters like temperature, oxidant/cat ratio, and subs/catalyst ratio affect the oxidation reactions were investigate the optimum conditions of catalysts. CBTAFePc shows excellent catalytic results on oxidation of Cyclohexene with the highest yield with good selectivity. The overall result shows that the CBTAFePc complex exhibits an excellent catalyst compared with the CBTACoPc complex for investigation of the oxidation of Cyclohexene.

\section{Materials and Methods}

\section{EXPERIMENTAL}

The high-grade solvents, reagents and chemicals are used without refinement (Sigma Aldrich $\mathrm{CGmbH}$, Sternheim, Germany). The reaction was performed in presence of an oxygen environment. All the chemicals were prepared by using distilled water. Iron and cobalt phthalocyanine prepared by literature. ${ }^{27-}$ 29

FTIR spectra have been recorded by Perkin Elmmer 1600 FT-IR spectrophotometer using KBr pellets. Micromass Quatro LC/MSD was used to measure the mass spectra. A Perkin Elmer Lambda 25 spectrophotometer in DMF was used to measure UV-Vis spectra. C, $\mathrm{H}$ and $\mathrm{N}$ analysis was done by Vario EL (III) CHNS analyzer. GC Agilent technologies 7820A equipment was used as GC measurement. Thermogravimetric analysis of the synthesized complexes was studied by the STA6000 system in the temperature range of 25 to $900{ }^{\circ} \mathrm{C}$ under the blowing rate of $20 \mathrm{~mL} \cdot \mathrm{min}^{-1}$ oxygen.

\section{Synthesis of Carbutamide Substituted Fe(II) phthalocyanine (CBTAFePc) Complex}

A mixture of carbutamide $(0.05 \mathrm{mmol})$, tetra carboxy-Fe(II)-phthalocyanine $(0.015 \mathrm{mmol})$, Potassium carbonate $(0.05 \mathrm{mmol})$ and DCC (catalytic quantities, in Dimethylformamide $40 \mathrm{~mL}$ ) was agitated under $\mathrm{N}_{2}$ atm for $30 \mathrm{~h}$ at $28{ }^{\circ} \mathrm{C}$. The greenish color compound formed. It was soaking with warm water after washing with methanol followed by $\mathrm{NaOH}, \mathrm{HCl}$ and double-distilled water. The obtained compound was dehydrated in an oven for nearly $45 \mathrm{~min}$ at $40-50{ }^{\circ} \mathrm{C}(\mathrm{Scheme}-1)$. Yield $=60 \%{ }^{30}$. Anal. For CBTAFePc with molecular weight and molecular formula 1759.70 (Experimental): $\mathrm{C}_{80} \mathrm{H}_{78} \mathrm{FeN}_{20} \mathrm{O}_{16} \mathrm{~S}_{4}$ calc. (\%) C54.60, H-4.432, N-15.91, O-14.53, S-7.28, Fe; 3.17 found: C-54.51, H-4.32, N-15.80, O-14.61, S-7.20, $\mathrm{Fe} ; 3.15$.

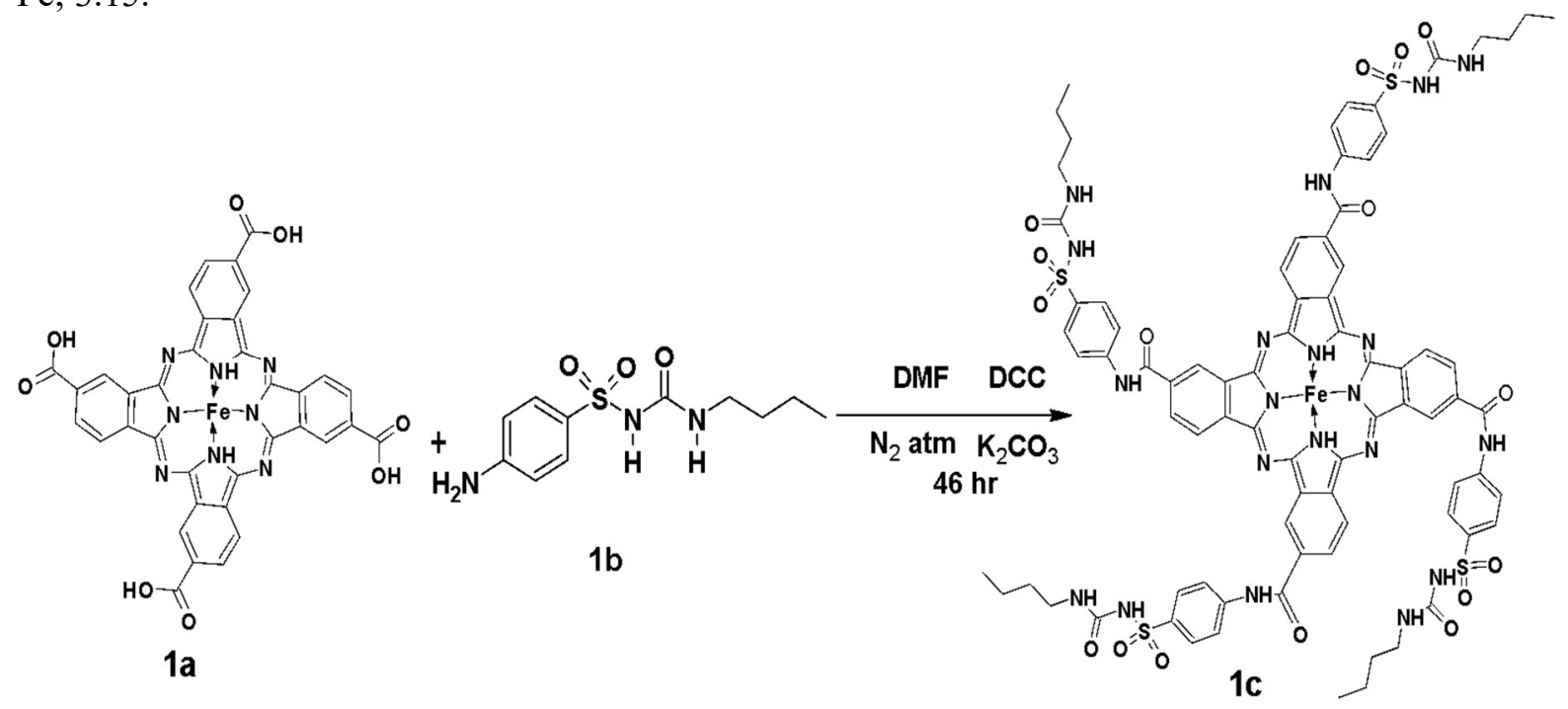

Scheme-1: Carbutamide Substituted-Fe(II)- phthalocyanine Complex Synthesis 


\section{Synthesis of Carbutamide Substituted Co(II) phthalocyanine (ODACoPc) Complex}

A mixture of carbutamide $(0.05 \mathrm{mmol})$, tetra carboxy-Co(II)-phthalocyanine $(0.015 \mathrm{mmol})$, Potassium carbonate $(0.05 \mathrm{mmol})$ and DCC (catalytic quantities, in Dimethylformamide $40 \mathrm{~mL}$ ) was agitated under $\mathrm{N}_{2}$ atmosphere for $30 \mathrm{~h}$ at $28{ }^{\circ} \mathrm{C}$. The greenish color compound formed. It was soaking with warm water after washing with methanol followed by $\mathrm{NaOH}, \mathrm{HCl}$ and double-distilled water. The obtained compound was dehydrated in an oven for nearly $45 \mathrm{~min}$ at $40-50{ }^{\circ} \mathrm{C}$ (Scheme-2). Yield $=65 \%{ }^{30}$. Anal. For CBTACoPc with molecular weight and molecular formula 1762.79 (Experimental): $\mathrm{C}_{80} \mathrm{H}_{78} \mathrm{CoN}_{20} \mathrm{O}_{16} \mathrm{~S}_{4}$ calc. (\%) C-54.60, H-4.432, N-15.91, O-14.53, S-7.28, Co; 3.34 found: C-54.49, H-4.38, N-15.86, O14.63, S-7.22, Co; 3.30 .

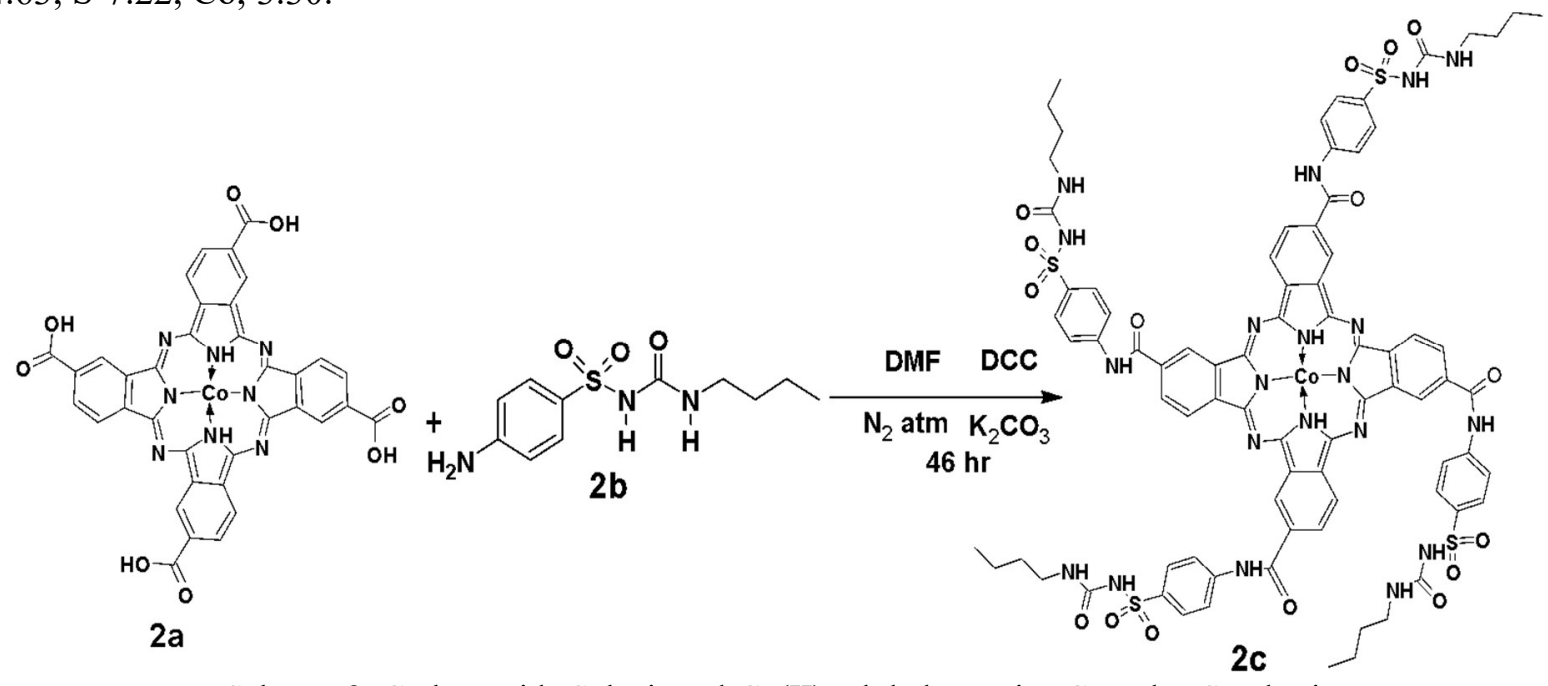

Scheme-2: Carbutamide Substituted-Co(II)- phthalocyanine Complex Synthesis

\section{Mechanism of Cyclohexene Oxidation}

The experiment was performed by a thermostated schlenk vessel fixed with a stirrer and condenser. The mixture of Cyclohexene, catalyst and desirable solvent were refining by passing $\mathrm{N}_{2}$ gas to the removal of oxygen. The mixture of Cyclohexene $\left(0.71 \times 10^{-3} \mathrm{~mol}\right)$, catalyst $\left(3.57 \times 10^{-6} \mathrm{~mol}\right)$ and solvent $(0.01 \mathrm{~L})$ was agitated in a vessel for $20 \mathrm{~min}$ at $28^{\circ} \mathrm{C}$, and then add $\mathrm{m}$-CPBA oxidant $\left(1.78 \times 10^{-3} \mathrm{~mol}\right)$ into the vessel. The whole mixture was agitated for the proper time. For each interval of time, the sample $(0.006 \mathrm{~L})$ was taken and each $1 \mu \mathrm{L}$ sample was injected into the GC at least two times. The formation of desired products was monitored by GC.

\section{FTIR-Spectra}

\section{RESULTS AND DISCUSSION}

The infrared spectroscopy was used for studying functional groups. The expected bands assignable to CBTAFePc and CBTACoPc complexes are found at 670-700, 750-790, 840-850, 940-945, 1090-1120, 1140-1147,1200-1210, 1240-1290, 1305-1320, 1400-1430, 1490-1540 and 1600-1625 $\mathrm{cm}^{-1}$. The IR bands of CBTAFePc $\left(\mathrm{KBr}\right.$ pellet), $\mathrm{v} / \mathrm{cm}^{-1}:$ 1622-1644 $(\mathrm{C}=\mathrm{C}), 2812-3013(\mathrm{C}=\mathrm{N}), 3212-3424$ (amide peak), 1492$1575(-\mathrm{C}=\mathrm{C}-\mathrm{N}=), 1318,1336,1258,1282,1232,1252,1152,1148(\mathrm{C}-\mathrm{O}), 1062,922,846,766,735$ Fig.1(A). The IR of CBTACoPc (KBr pellet), v/cm ${ }^{-1}$ : 1624-1648 $(\mathrm{C}=\mathrm{C}), 2814-3016(\mathrm{C}=\mathrm{N}), 3216-3433$ (amide peak), 1494-1578 (-C=C-N=), 1319, 1336, 1258, 1296, 1234, 1255, 1152, 1144 (C-O), 1062, 924, 847, 769, 731 Fig.-1(B). ${ }^{31}$

\section{UV-Vis Spectroscopy}

The electronic spectra of CBTAFePc and CBTACoPc complex solutions are shown in Fig.-2. The absorption shows two intense peaks. The intense absorption peak at $650-750 \mathrm{~nm}$ was assigned for Q-Band $[\mathrm{a} 1 \mathrm{u} \rightarrow \operatorname{eg}(*)]$ for the $\pi-\pi^{*}$ transitions from the HUMO to the LUMO and $300-500 \mathrm{~nm}$ is B-band of CBTAFePc and CBTACoPc complexes ${ }^{32}$. The UV spectra of MPc (M=Fe and Co) are observed in the range of $650-750 \mathrm{~nm}$. This indicates the formation of CBTAFePc and CBTACoPc complexes. 
RASĀYAN J. Chem.

Vol. 14 | No. 3 |1761-1772| July - September | 2021
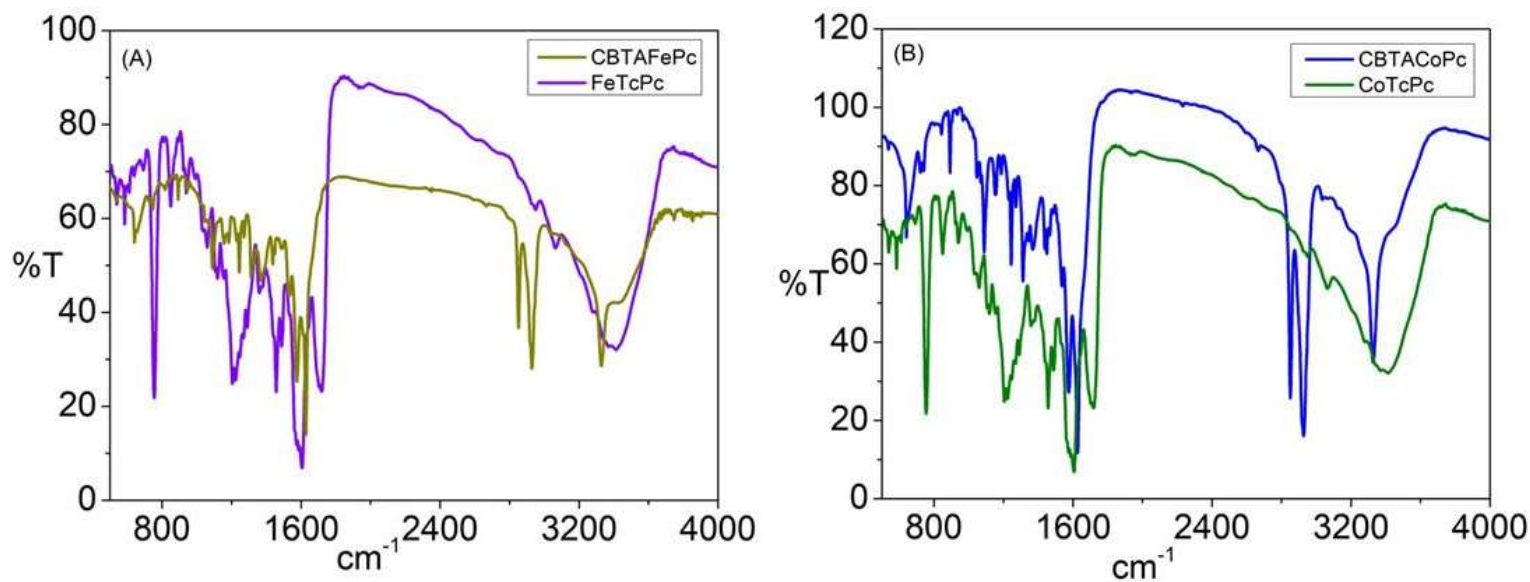

Fig.-1: IR Absorption Spectra of (A) CBTAFePc with FeTcPc (B) CBTACoPc with CoTcPc

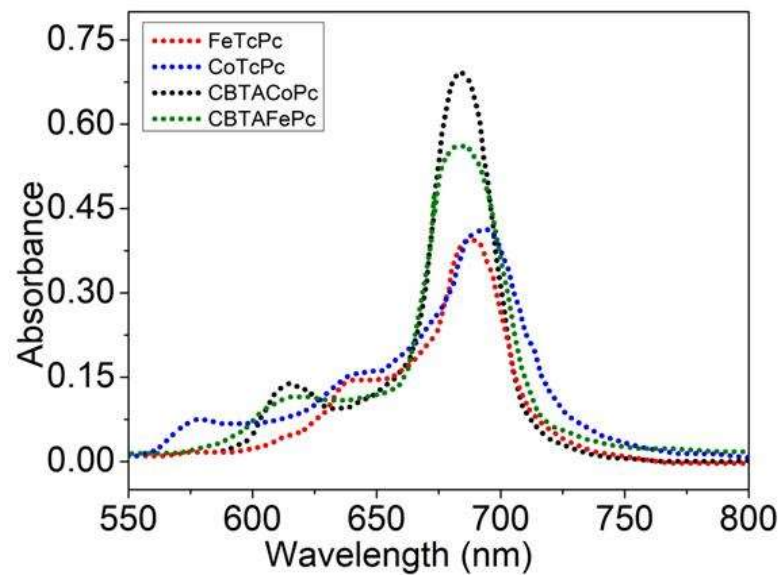

Fig.-2: UV-Vis Spectrum of CBTAFePc with FeTcPc and CBTACoPc with CoTcPc Complexes

\section{Thermogravimetric Analysis}

The Thermogram of CBTAFePc and CBTACoPc complexes Fig.-3 shows the stability of the molecule. The CBTAFePc and CBTACoPc show two-step degradation, one at $200{ }^{\circ} \mathrm{C}$ and the other at $300{ }^{\circ} \mathrm{C}$. Degradation at $200{ }^{\circ} \mathrm{C}$ corresponds to a loss of carbutamide and at $300{ }^{\circ} \mathrm{C}$ loss of phthalocyanine ring and weight loss at $550{ }^{\circ} \mathrm{C}$ is due to complete degradation to form metal oxide. The presence of the substituted group improves the thermal stability of the CBTAFePc and CBTACoPc complexes. The melting point of the molecule is very high $\geq 550{ }^{\circ} \mathrm{C}^{33}$. Therefore, the CBTAFePc and CBTACoPc complexes are used in the determination of oxidation of Cyclohexene.

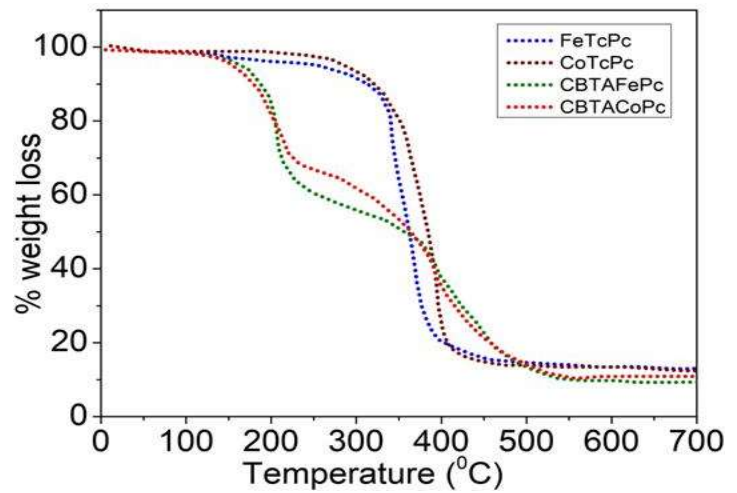

Fig.-3: Thermogravimetric Analysis of CBTAFePc with FeTcPc and CBTACoPc with CoTcPc Complexes 


\section{XRD Analysis}

The powder XRD of CBTAFePc and CBTACoPc complexes are attained by Co-k $\alpha$ radiation $(\lambda=1.540$ $\mathrm{A}^{\circ}$ ). It denotes that the CBTAFePc and CBTACoPc complexes are amorphous. The diffraction pattern of these complexes exhibits broad peaks with various diffused intensities. The peak intensity slowly increased by an increase in carbutamide groups. XRD patterns for the synthesized complexes were noted in the $2 \theta$ angle range of $0-60{ }^{\circ} \mathrm{C}$ as shown in Fig.-4. The less intensity peaks were observed at $2 \theta$ values of less intensity peaks at $11.50^{\circ}, 12.65^{\circ}, 23.12^{\circ}, 24.40^{\circ}, 32.04^{\circ}, 46.55^{\circ}, 47.42^{\circ}, 58.02^{\circ}$ and $59.85^{\circ}$ for CBTAFePc complex and $07.06^{\circ}, 11.20^{\circ}, 17.52^{\circ}, 18.39^{\circ}, 19.20^{\circ}, 20.00^{\circ}, 30.39^{\circ}, 31.20^{\circ}$ and $40.39^{\circ}$ for CBTACoPc complex, at $2 \theta$ values of high intensity peaks at $6.50^{\circ}, 21.65^{\circ}, 39.12^{\circ}, 40.39^{\circ}$, and $55.85^{\circ}$ for CBTAFePc complex and $07.08^{\circ}, 8.00^{\circ}, 09.12^{\circ}, 10.39^{\circ}, 11.50^{\circ}, 15.65^{\circ}, 21.12^{\circ}, 25.39^{\circ}$ and $41.39^{\circ}$ for CBTACoPc complex. This indicates CBTAFePc and CBTACoPc complexes are amorphous. ${ }^{34}$
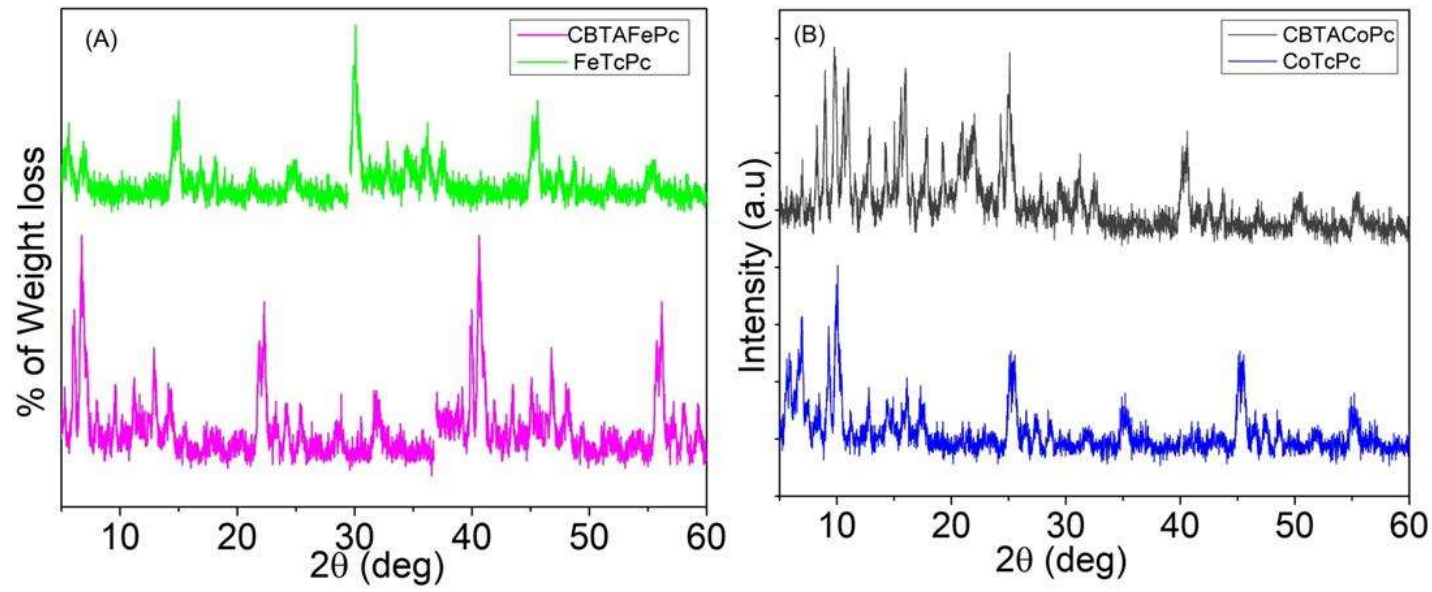

Fig.-4: XRD Analysis of (A) CBTAFePc with FeTcPc (B) CBTACoPc with CoTcPc Complexes

\section{Elemental Analysis of CBTAFePc and CBTACoPc Complexes}

Elemental analysis for $\mathrm{C}, \mathrm{H}$ and $\mathrm{N}$ was done by Vario EL (III) C.H.N.S analyzer. The CBTAFePc and CBTACoPc were examined by a known quantity of the complexes with $\mathrm{H}_{2} \mathrm{SO}_{4}$ and $\mathrm{HNO}_{3}$ mixture, followed by careful evaporation and calcinations. ${ }^{31-32}$ Anal. For CBTAFePc with molecular weight and molecular formula 1759.7026 (Experimental): $\mathrm{C}_{80} \mathrm{H}_{78} \mathrm{FeN}_{20} \mathrm{O}_{16} \mathrm{~S}_{4}$ calc. (\%) C-54.60, H-4.432, N-15.91, O14.53, S-7.28, Fe; 3.17 found: C-54.51, H-4.32, N-15.80, O-14.61, S-7.20, Fe; 3.15. Anal. For CBTACoPc with molecular weight and molecular formula 1762.79 (Experimental): $\mathrm{C}_{80} \mathrm{H}_{78} \mathrm{CoN}_{20} \mathrm{O}_{16} \mathrm{~S}_{4}$ calc. (\%) C-54.60, H-4.432, N-15.91, O-14.53, S-7.28, Co; 3.34 found: C-54.49, H-4.38, N-15.86, O14.63, S-7.22, Co; 3.30 .

\section{Mass Spectrum}

Mass spectroscopy (MS) is used to measure the mass to charge ratio [M+2] of compounds. The theoretical observation of mass spectra of the CBTAFePc complex is 1759.7026 and the experimental mass of the CBTAFePc exhibits a molecular ion peak at 1761.63 Fig.-5. It indicates the conformation of the formation of proposed complex.

\section{Aggregation Behavior of CBTAFePc Complex}

The aggregation property of CBTAFePc was analyzed by the UV-Vis method. The synthesized complex has $18 \pi$-electron systems so that it shows aggregation behavior. The aggregation mainly depends on temperature, substituents, concentration and solubility. The CBTAFePc complex shows H-type and J-type aggregation that depends on the position of the substituents. Majorly the Fe-Pc showed H-type aggregation more in solvents and rarely observing J-type aggregation ${ }^{30}$. For measurement of aggregation behavior, we used Beer-Lambert law in the concentration range from $30 \times 10^{-5}$ to $5 \times 10^{-5} \mathrm{~mol} \mathrm{dm}^{-3}$. In the present work aggregation property of the CBTAFePc complex was performed by different solvents such as DMF, DMSO, $\mathrm{CCL}_{4}$ and $\mathrm{CHCl}_{3}$ Fig.-6A. it shows that more aggregation takes place in DMF and 
DMSO solvent due to the high solubility of the compound and less aggregation in $\mathrm{CCL}_{4}$ and $\mathrm{CHCl}_{3}$. The aggregation property of the CBTAFePc complex was also studied by using various concentrations of DMF solvent Fig.-6B, as the concentration of the DMF solvent increases the absorption peak intensity (Q-band) also increases. All the above results show that the aggregation behavior of the CBTAFePc was high in DMF solvent with high concentration.

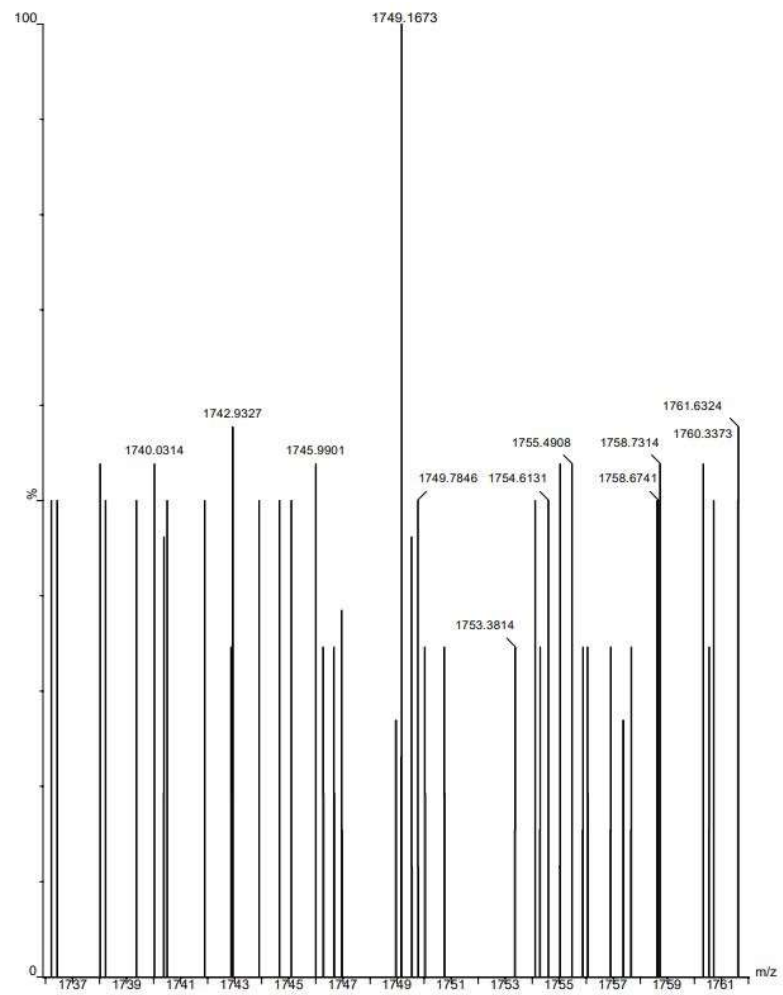

Fig.-5: Mass Spectra of CBTAFePc Complex
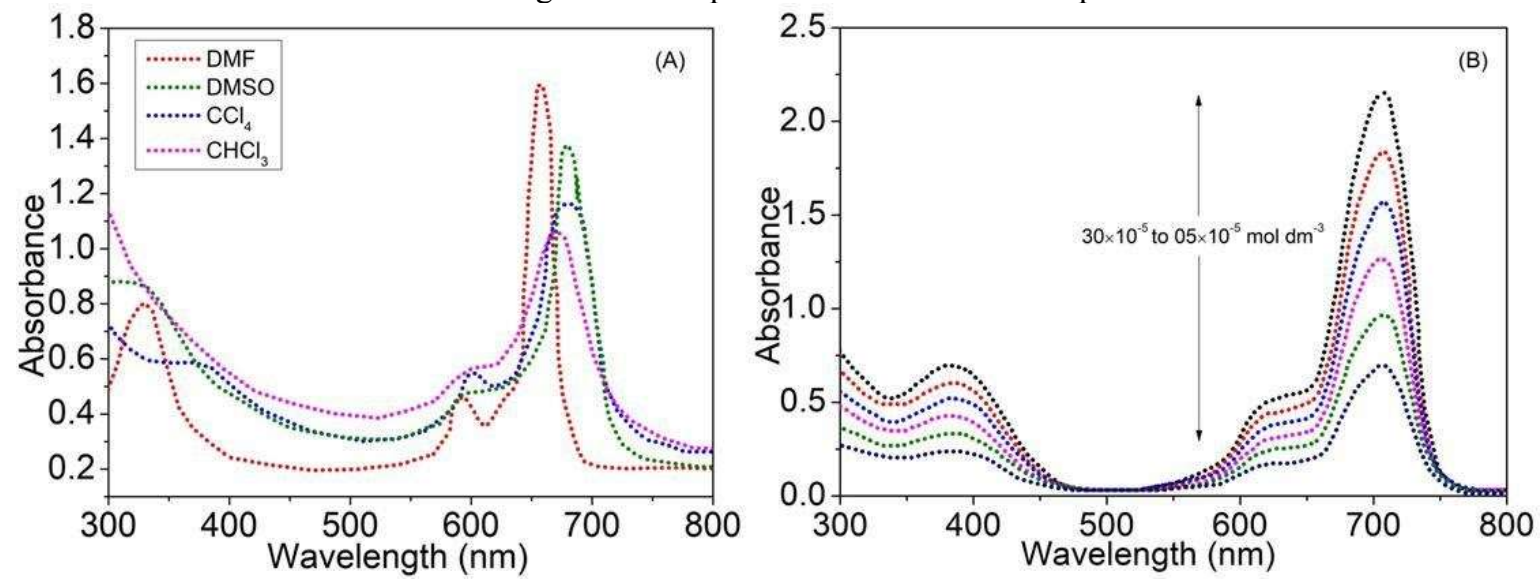

Fig.-6: Aggregation Property of CBTAFePc (A) Different Solvents of DMF, DMSO, $\mathrm{CCL}_{4}$ and $\mathrm{CHCl}_{3}$, (B)

Different Concentrations of DMF Solvents

\section{Catalytic Investigation}

\section{Cyclohexene Oxidation with CBTAFePc and CBTACoPc}

The selectivity and catalytic activity (CA) of CBTAFePc and CBTACoPc complexes were studied by simple Cyclohexene oxidation method with $\mathrm{m}$-CPBA as the model compound in experimental parameters in DMF (Tables-1 to 4), the oxidation of Cyclohexene was carried out by Cyclohexene $\left(0.71 \times 10^{-4} \mathrm{~mol}\right)$, CBTAFePc $\left(3.58 \times 10^{-7} \mathrm{~mol}\right)$ or CBTACoPc $\left(3.57 \times 10^{-7} \mathrm{~mol}\right)$ and $\mathrm{m}-\mathrm{CPBA}\left(1.78 \times 10^{-4} \mathrm{~mol}\right)$ and DMF $(001$ L) in a vessel and refluxed at $90{ }^{\circ} \mathrm{C}$ with stirring $800 \mathrm{rpm}$. The experiment was also performed by various 
oxidants like TBHP, $\mathrm{H}_{2} \mathrm{O}_{2}$ and $\mathrm{m}-\mathrm{CPBA}$ in absence of catalyst, the results give evidence for the oxidation of Cyclohexene, the catalyst is very important for the completion of the reaction. Therefore the catalyst is playing an important role in the oxidation of Cyclohexene seen in Tables-1 to 4 . The comparative studies of CBTAFePc and CBTACoPc for Cyclohexene oxidation exhibits both the compounds are active catalysts in DMF solvents, which gives Cyclohexenol as the major product and Cyclohexene epoxide and 2-cyclohexen-1-one is a minor product, these are analyzed by GC for both penetrate and comparison with standards Scheme-3. The reaction rate increased by varying the oxidants, sub/cat. ratio and temperature.

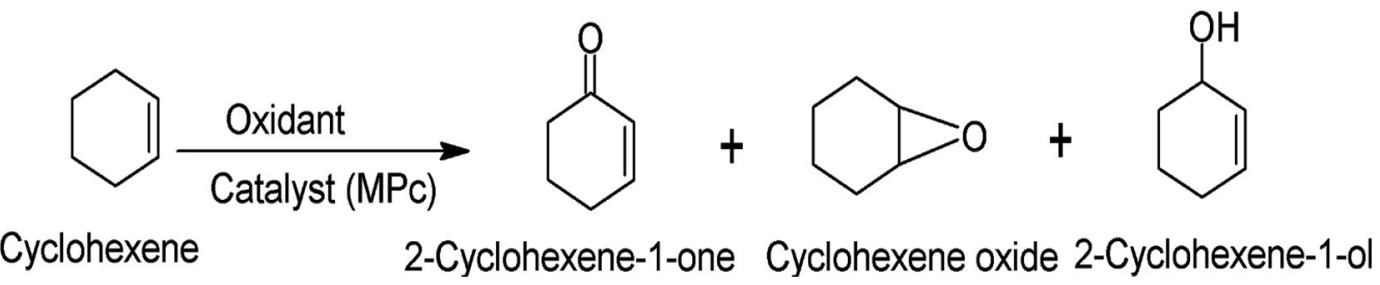

Scheme-3: Mechanism of Oxidation of Cyclohexene

The results of Cyclohexene oxidation by $\mathrm{m}-\mathrm{CPBA}$ in presence of CBTAFePc and CBTACoPc as seen in Fig.-7A and Fig.-7B, indicates that the product yield is varied with reaction time. High yield was formed that is 2-cyclohexen-1-ol as the major product and Cyclohexene epoxide and 2-cyclohexen-1-one is a minor product for both catalysts. The yields for Cyclohexeneepoxide and Cyclohexenone were nearly similar to the catalysts CBTAFePc and CBTACoPc. The three product yields increased by the same level of time. This level off is most likely due to degradation of the Fe-Pc and Co-Pc catalyst by oxidant with time.

The substrate to catalytic molar ratio effect was examined in the range of 200-1200 and kept other parameters constants. The experimental conditions were $90{ }^{\circ} \mathrm{C}, 1.78 \times 10^{-4} \mathrm{~mol} \mathrm{~m}-\mathrm{CPBA}, 0.01 \mathrm{~L}$ DMF for $3 \mathrm{~h}$. the results are seen in Table-1. It gives clear evidence, as the substrate catalytic ratio decreases the increase of conversion. For each various substrate/catalyst ratio the Cyclohexene oxidation gives the same a2-Cyclohexene-1-ol as the major product and ${ }^{\mathrm{C} C y c l o h e x e n e ~ e p o x i d e ~ a n d ~}{ }^{\mathrm{b}}$ 2-cyclohexen-1-one is a minor product. The major product gives a good selectivity of $60 \%$ and $57 \%$ for CBTAFePc and CBTACoPc.
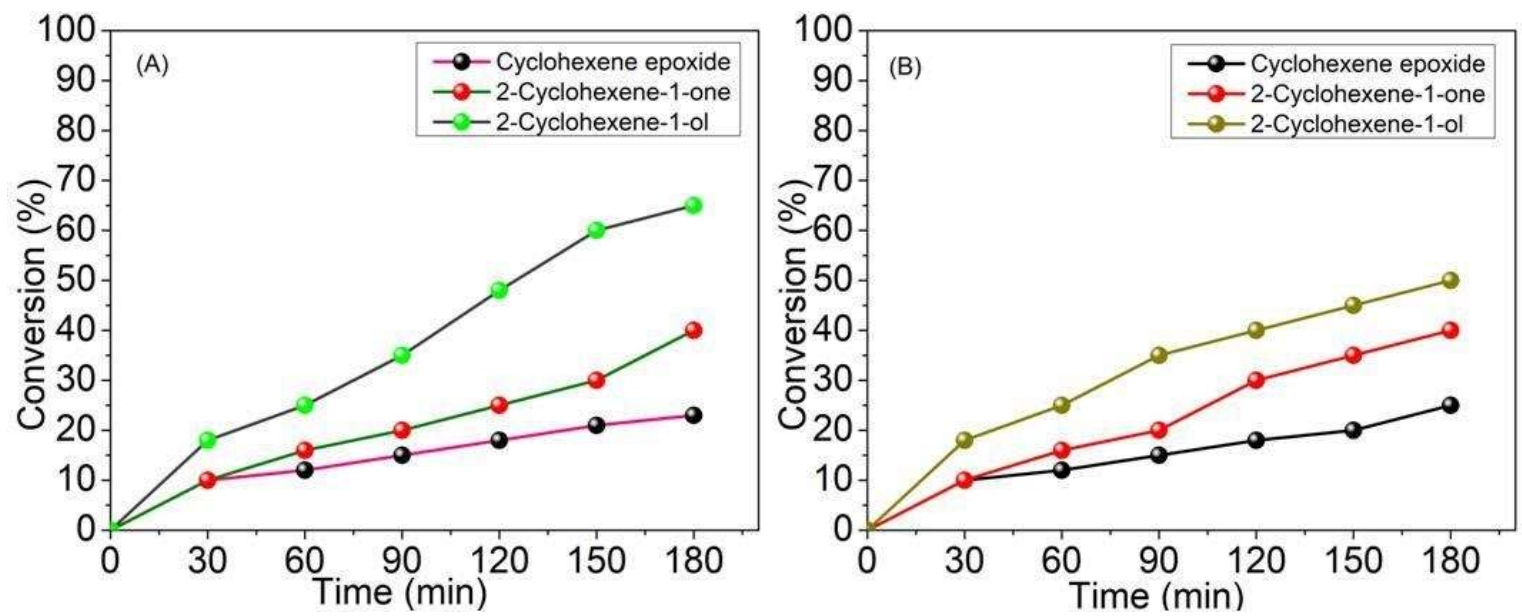

Fig.-7: Cyclohexene Oxidation (Time dependent) with (A) CBTAFePc (B) CBTACoPc

The oxygen source effect on the oxidation of Cyclohexene reaction was scrutinized for m-CPBA, aerobic oxygen, TBHP and $\mathrm{H}_{2} \mathrm{O}_{2}$, remaining all the experimental parameters kept constant. The obtained results are as shown in Table-2 and Fig.-8. In aerobic oxygen conditions, both complexes are not converted. In this experiment, the Cyclohexene oxidation is more effective in the m-CPBA oxidant with CBTAFePc and CBTACoPc. The same experiment was performed without $\mathrm{m}$-CPBA oxidant; the oxidation reaction of Cyclohexene does not take place. Therefore m-CPBA shows a good oxidant effect on the oxidation of 
RASĀYAN J. Chem.

Vol. 14 | No. 3 |1761-1772| July - September | 2021

Cyclohexene. The other oxidants like TBHP and $\mathrm{H}_{2} \mathrm{O}_{2}$ are not suitable oxidants for the catalytic system. The main reason we observed in the process is that the lower conversion of $\mathrm{H}_{2} \mathrm{O}_{2}$ undergoes degradized the CBTAFePc and CBTACoPc ring.

Table-1: Effect of Substrate to Catalytic Ratio on Cyclohexene Oxidation with CBTAFePc and CBTACoPc

\begin{tabular}{c|c|c|c|c|c|c|c}
\hline Catalyst & Subs/Cat & ${ }^{\mathrm{a}}$ Alcohol & ${ }^{\mathrm{b}}$ Ketone & ${ }^{\mathrm{c}}$ Epoxide & $\begin{array}{c}\text { Tot. } \\
\text { Conv. } \\
(\%)\end{array}$ & $\begin{array}{c}\text { TON } \\
\text { mole of } \\
\text { product/mole } \\
\text { of catalyst }\end{array}$ & $\begin{array}{c}\text { TOF }\left(\mathrm{h}^{-1}\right) \\
\text { mole of } \\
\text { product/mole of } \\
\text { catalyst } \times \text { time }\end{array}$ \\
\hline 1c & $200 / 1$ & 60 & 20 & 19 & 99 & 195 & 64 \\
\hline 2c & & 57 & 17 & 12 & 85 & 168 & 55 \\
\hline 1c & $400 / 1$ & 58 & 18 & 14 & 90 & 355 & 118 \\
\hline 2c & & 54 & 15 & 09 & 78 & 310 & 102 \\
\hline $1 \mathrm{c}$ & $600 / 1$ & 53 & 14 & 12 & 79 & 369 & 155 \\
\hline 2c & & 50 & 10 & 05 & 65 & 386 & 128 \\
\hline $1 \mathrm{c}$ & $800 / 1$ & 48 & 12 & 07 & 67 & 530 & 176 \\
\hline 2c & & 44 & 06 & 03 & 53 & 420 & 139 \\
\hline $1 \mathrm{c}$ & $1000 / 1$ & 39 & 10 & 07 & 56 & 554 & 184 \\
\hline 2c & & 36 & 05 & 04 & 45 & 446 & 148 \\
\hline $1 \mathrm{c}$ & $1200 / 1$ & 33 & 10 & 06 & 49 & 582 & 193 \\
\hline 2c & & 28 & 06 & 04 & 38 & 452 & 150 \\
\hline
\end{tabular}

Then the color of the solution immediately turns colorless from blue-green color. Therefore the CBTAFePc and CBTACoPc do not involve effectively as a catalyst in the oxidation process. The same experiment is performed by TBHP. It shows more degradation compared with $\mathrm{H}_{2} \mathrm{O}_{2}$. All the above results show that the highest activity of CBTAFePc and CBTACoPc takes place in the presence of m-CPBA (TOF: 98 and 90) and other oxidant activity as shown in Table-2.

Table-2: Oxygen Source Effect on Cyclohexene Oxidation with CBTAFePc and CBTACoPc

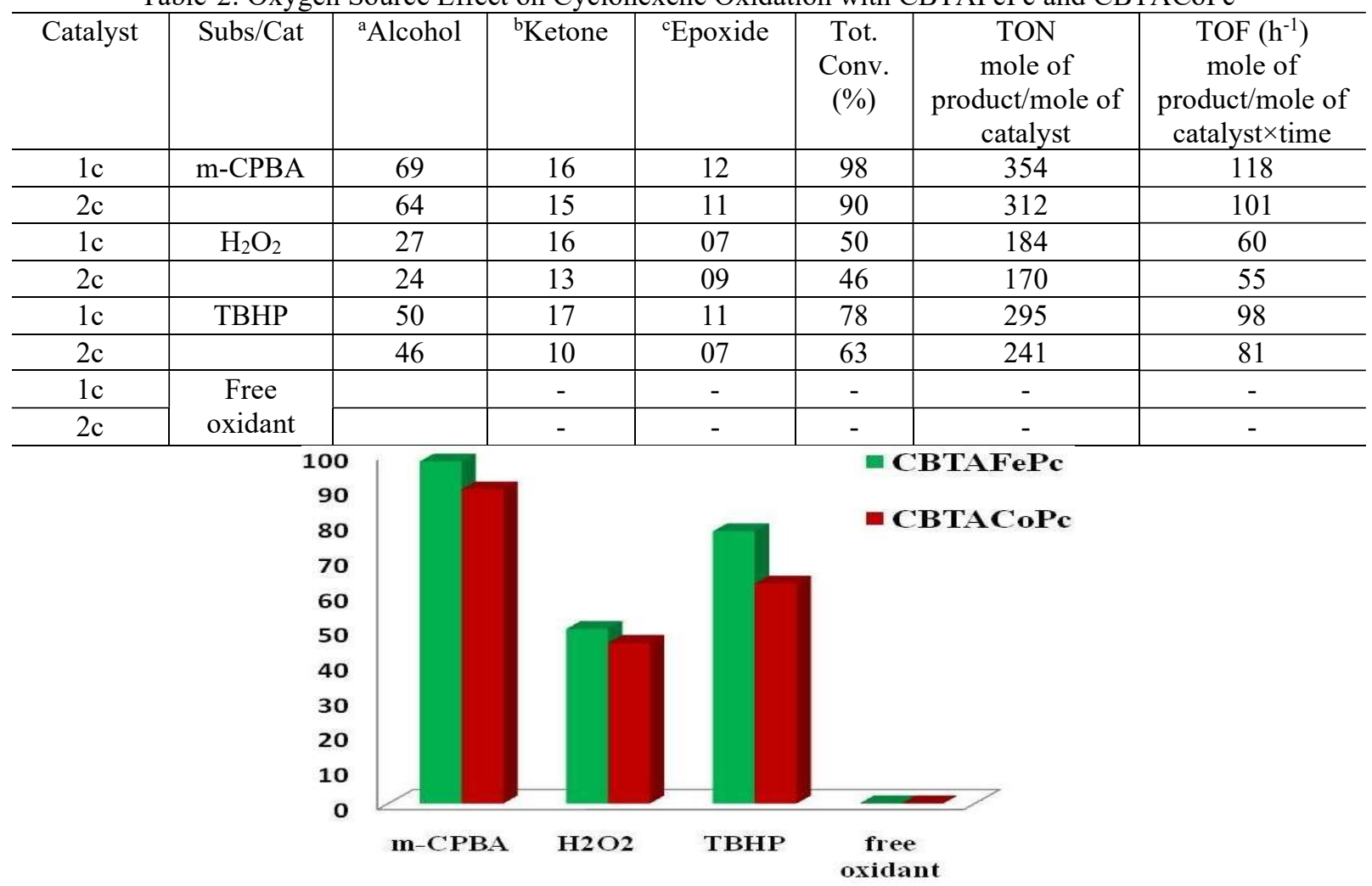

Fig.-8: The Oxidant Effect on the Oxidation of Cyclohexene 
RASĀYAN J. Chem.

Vol. 14 | No. 3 |1761-1772| July - September | 2021

The other important parameter involving the oxidation reaction is a substrate to oxidant ratio, the reaction was performed in the range of 300/1-900/1 as seen in Table-3. The rate of oxidation reaction enhances with increasing oxidant/cat. ratio up to 500/1. Further increasing the ratio, the catalytic conversion decreases. It is very difficult to conclude the effect of oxidant at the present stage, but it is possible that the coordination around the iron and cobalt, iron may change and produce in-active intermediate species.

Table-3: Effect of Substrate to Oxidant Ratio on Cyclohexene Oxidation with CBTAFePc and CBTACoPc

\begin{tabular}{c|c|c|c|c|c|c|c}
\hline Catalyst & Subs/Cat & ${ }^{a}$ Alcohol & ${ }^{b}$ Ketone & ${ }^{\mathrm{c} E p o x i d e}$ & $\begin{array}{c}\text { Tot. } \\
\text { Conv. } \\
(\%)\end{array}$ & $\begin{array}{c}\text { TON } \\
\text { mole of } \\
\text { product/mole of } \\
\text { catalyst }\end{array}$ & $\begin{array}{c}\text { TOF }\left(\mathrm{h}^{-1}\right) \\
\text { mole of } \\
\text { product/mole of } \\
\text { catalyst } \times \text { time }\end{array}$ \\
\hline 1c & $300 / 1$ & 34 & 18 & 15 & 66 & 258 & 87 \\
\hline 2c & & 30 & 15 & 10 & 55 & 215 & 73 \\
\hline 1c & $400 / 1$ & 43 & 21 & 16 & 80 & 314 & 106 \\
\hline 2c & & 40 & 18 & 14 & 70 & 279 & 94 \\
\hline 1c & $500 / 1$ & 64 & 16 & 10 & 90 & 357 & 120 \\
\hline 2c & & 58 & 12 & 08 & 78 & 311 & 105 \\
\hline $1 \mathrm{c}$ & $600 / 1$ & 36 & 18 & 15 & 69 & 370 & 90 \\
\hline 2c & & 32 & 18 & 11 & 59 & 228 & 76 \\
\hline 1c & $900 / 1$ & 26 & 11 & 05 & 42 & 168 & 57 \\
\hline 2c & & 21 & 08 & 06 & 35 & 140 & 47 \\
\hline
\end{tabular}

The temperature is also one of the critical parameters for catalytic oxidation of Cyclohexene with $\mathrm{CBTAFePc}$ and CBTACoPc. The CA increases by increasing the temperature. The experiment was performed in the range of $20-90{ }^{\circ} \mathrm{C}$ with ox./subst./cat $=500 / 200 / 1$ and $\mathrm{m}-\mathrm{CPBA}$ in DMF for $3 \mathrm{~h}$ as seen in Table-4. The overall conversion was increased $61 \%$ for CBTAFePc and $53 \%$ for CBTACoPc, when the temperature was increased from 20 to $90{ }^{\circ} \mathrm{C}$. The highest conversion $(99 \%)$ was obtained with $\mathrm{TOF}=65$ for complex CBTAFePc and (85\%) was obtained with $\mathrm{TOF}=56$ for complex $\mathrm{CBTACoPc}$ at $90^{\circ} \mathrm{C}$.

Table-4: Effect of Temperature on Cyclohexene Oxidation with CBTAFePc and CBTACoPc

\begin{tabular}{c|c|c|c|c|c|c|c}
\hline Catalyst & Subs/Cat & ${ }^{\mathrm{a}}$ Alcohol & ${ }^{\mathrm{b} K e t o n e}$ & ${ }^{\mathrm{c}}$ Epoxide & $\begin{array}{c}\text { Tot. } \\
\text { Conv. } \\
(\%)\end{array}$ & $\begin{array}{c}\text { TON } \\
\text { mole of } \\
\text { product/mole } \\
\text { of catalyst }\end{array}$ & $\begin{array}{c}\text { TOF }\left(\mathrm{h}^{-1}\right) \\
\text { mole of } \\
\text { product/mole of } \\
\text { catalyst } \times \text { time }\end{array}$ \\
\hline $1 \mathrm{c}$ & 25 & 26 & 14 & 09 & 49 & 95 & 31 \\
\hline 2c & & 23 & 12 & 09 & 44 & 83 & 27 \\
\hline $1 \mathrm{c}$ & 50 & 42 & 16 & 10 & 68 & 134 & 44 \\
\hline 2c & & 39 & 12 & 09 & 60 & 117 & 39 \\
\hline $1 \mathrm{c}$ & 70 & 53 & 18 & 12 & 83 & 164 & 54 \\
\hline 2c & & 50 & 13 & 10 & 73 & 141 & 47 \\
\hline $1 \mathrm{c}$ & 90 & 69 & 23 & 19 & 99 & 196 & 65 \\
\hline 2c & & 60 & 19 & 16 & 85 & 169 & 56 \\
\hline
\end{tabular}

The performance of CBTAFePc and CBTACoPc catalytic activity on oxidation of Cyclohexene was compared with other M-porphyrin and MPc catalysts (like Fe, Mn and Co). We get the best results in the form of TOF in Cyclohexene oxidation. We have also noted that the CBTAFePc was acting as the best catalyst compared with CBTACoPc.

The oxidation reaction system was monitoring by absorption spectroscopy in the 300 to $800 \mathrm{~nm}$ range of CBTAFePc and CBTACoPc, shows two strong absorptions bands assigned to the transition $\mathrm{n}-\mathrm{p}^{*}$ and $\mathrm{p}$ $\mathrm{p}^{*}$. The intense absorption peak observed at $650-750 \mathrm{~nm}$ is assigned for Q-Band and one more absorption peak at $300-450 \mathrm{~nm}$ is assigned for B-band. ${ }^{30-32}$ These bands are also found in the CBTAFePc and 
RASĀYAN J. Chem.

Vol. 14 | No. 3 |1761-1772| July - September | 2021

CBTACoPc. But they shift and broadens due to m-oxo dimeric species of Fe(II)-Pc to $\mathrm{Fe}(\mathrm{III})-\mathrm{Pc}$ and $\mathrm{Co}(\mathrm{II})-\mathrm{Pc}$ to $\mathrm{Co}(\mathrm{III})-\mathrm{Pc} .^{33-35}$

Table-5: The Homogeneous Catalytic Oxidation of Cyclohexene by the previously reported Catalysts

\begin{tabular}{l|c|c|c|c|c}
\hline Catalyst & Reaction time $(\mathrm{h})$ & Reaction Temp. $\left({ }^{\circ} \mathrm{C}\right)$ & Oxidant & Conv. (\%) & Ref. \\
\hline $\mathrm{CoPc}$ & 8 & 60 & TBHP & 45.3 & {$[37]$} \\
\hline$\left[\mathrm{Co}\left(\mathrm{Me}_{2} \mathrm{salpnMe}_{2}\right)\right]$ & 8 & 75 & $\mathrm{H}_{2} \mathrm{O}_{2}$ & 27.6 & {$[38]$} \\
\hline $\mathrm{CoPc}$ & 3 & 90 & m-CPBA & 61 & {$[39]$} \\
\hline$\left[\mathrm{Mn}\left(\mathrm{Me}_{2} \mathrm{SalpnMe}_{2}\right)\right]$ & 8 & 40 & TBHP & 50.9 & {$[40]$} \\
\hline $\mathrm{Fe}(\mathrm{TMP}) \mathrm{Cl}$ & $10 \mathrm{~min}$ & 25 & m-CPBA & 89 & {$[41]$} \\
\hline $\mathrm{Co}[\mathrm{NO}]_{2} \mathrm{Cu}[\mathrm{NO}]_{2}$ & 8 & 75 & $\mathrm{H}_{2} \mathrm{O}_{2}$ & 27.6 & {$[42]$} \\
\hline $\mathrm{CBTAFePc}$ & 3 & 90 & m-CPBA & 99 & $\begin{array}{c}\text { Present } \\
\text { work }\end{array}$ \\
\hline CBTACoPc & 3 & 90 & m-CPBA & 85 & \multirow{2}{*}{} \\
\hline
\end{tabular}
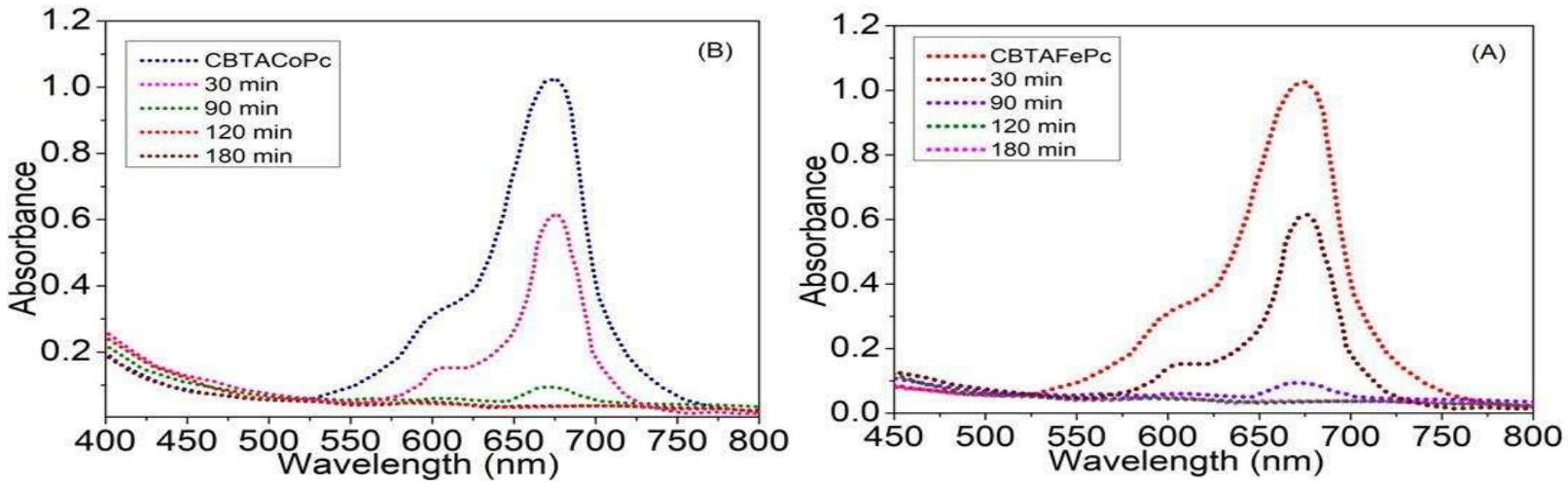

Fig.-9: Time Dependent Variation in the Visible Spectrum of the Oxidized Complex (A) CBTAFePc (B)

CBTACoPc

Figures-9A and 9B show changes in the spectrum of CBTAFePc and CBTACoPc during the oxidation reaction with m-CPBA. The monomeric form of MPc is shown in Fig.-2 before the start of the catalytic reactions. The Q-band was observed at $670 \mathrm{~nm}$ for both the complexes CBTAFePc and CBTACoPc respectively. With oxidants (TBHP, m-CPBA, or $\mathrm{H}_{2} \mathrm{O}_{2}$ ), the decrease of intensity and broadens Q-band peaks at 657 and $665 \mathrm{~nm}$. In the B-band region, there is no peak observed. Thus the addition of m-CPBA to the solutions of $\mathrm{Fe}$ (II) and $\mathrm{Co}$ (II) complexes resulted in only metal and not ring oxidation of Fe-Pc and Co-Pc. As the process of catalytic activity increases there is a decrease in the intensity of Q-band of the CBTAFePc and CBTACoPc, suggesting catalyst degradation is typical of MPc catalysts in homogeneous catalysis. ${ }^{36}$ The m-CPBA produces alkylperoxide and alkoxy radicals, these radicals degradized the MPc ring and were observed by the change in the color of the solution from blue to green by continuing the catalytic reaction. If the reaction is continued the catalyst is turned to yellow color, which gives the formation of intermediate in the reaction. The process is continued and the MPcs undergo degradized by the oxidant. The UV Vis method is used for the determination of the degradation of the compounds. The overall results suggest that the $\mathrm{CBTAFePc}$ and $\mathrm{CBTACoPc}$ exists a long durable reaction time with effective catalytic activity without degradation of oxidation of Cyclohexene.

\section{CONCLUSION}

The Carbutamide substituted $\mathrm{Fe}(\mathrm{II})$ phthalocyanine (CBTAFePc) and $\mathrm{Co}(\mathrm{II})$ phthalocyanine (CBTACoPc) complex was synthesized from tetracarboxylic acid $\mathrm{Fe}(\mathrm{II})$ phthalocyanine (FeTcPc) and tetracarboxylic acid $\mathrm{Co}$ (II) phthalocyanine ( $\mathrm{CoTcPc}$ ) with Carbutamide (CBTA) by linkage of an amide has been developed. The macrocyclic molecules have high molecular weight and the molecule is completely soluble in Dimethylformamide and Dimethylsulfoxide. The CBTAFePc and CBTACoPc were confirmed by FTIR, Ultraviolet-Visible, PXRD and Thermo-gravimetric techniques. The catalytic activity 
RASĀYAN J. Chem.

Vol. 14 | No. 3 |1761-1772| July - September | 2021

of CBTAFePc and CBTACoPc complexes were analyzed in the oxidation of Cyclohexene with various parameters like temperature, types of oxidants, oxidant/cat ratio, and subs/catalyst ratio affect the oxidation reactions were investigate the optimum conditions of catalysts. CBTAFePc shows excellent catalytic results on oxidation of Cyclohexene with the highest yield with good selectivity. The overall results show that the CBTAFePc complex exhibits an excellent catalyst compared with the CBTACoPc complex for investigation of the oxidation of Cyclohexene.

\section{ACKNOWLEDGMENT}

One of the author's T.M. Sharanakumar thanks Vijayanagara Srikrishnadevaraya University, Ballari, BITM College, Ballari for facilities and encouragement.

\section{REFERENCES}

1. I. Umit, Ph.D. thesis, Gebze Institue of Technology, (2007). https://doi.org/10.1016/j.jorganchem.2013.07.013

2. P. $\mathrm{Wu}, \mathrm{T}$. Tatsumi, T. Komatsu, T. Yashima, Journal of Catalysis, 202, 245 (2001). https://doi.org/10.1006/jcat.2001.3278

3. M.J. Cook, N.B.Mc. Keown J.M. Simmons A.J. Thomson M.F. Daniel. K.J. Harrison, R.M. Richsrdson, S.J. Roser, Journal of Material Chemistry,1, 11(1991).

4. Z. Odabas, A. Altindal, A. R Ozkaya, M. Bulut, Polyhedran, 26, 3505(2007), https://doi.org/10.1016/i.poly.2007.03.047

5. K.M. Kadish, K.M. Smith, R.Guilard (Eds.), the Porhyrine, Phthalocyanine: Synthesis of Phthalocyanine Precursors, Vol.15 (Chap.97), California (2003), https://doi.org/10.1080/00958972.2018.1423560

6. J. Cynthia M, Allen, Wesley M, Sharman and Johan E, Van Lier, Journal of Porphyrins and Phthalocyanines, 5(2), 161(2001), https://doi.org/10.1002/jpp.324

7. Qiwen Lai, Md Zakaria Quadir and Kondo-Francois Aguey-Zinsou, ACS Applied Energy Materials, 12(1), 6824(2018), https://doi.org/10.1021/acsaem.8b01087

8. Nana Wang, Junsheng Yu, Yue Zang, Jiang Huang, Yadong Jiang, Solar Energy Materials and Solar Cells, 94(2), 263(2010), https://doi.org/10.1016/j.solmat.2009.09.012

9. C.C. Lenzoff, A.B.P. Lever (Eds.), Phthalocyanine: Properties and Applications, Vol.1, VCH Publisher, New York (1989), https://doi.org/10.1002/adma.19930051217

10. C.C. Lenzoff, A.B.P. Lever (Eds.), Phthalocyanine: Properties and Applications, Vol.2, VCH Publisher, New York (1993).

11. I. Ozcesmeci, S. Guner, A. I. Okur, A. Gul. Journal of Porphyrins Phthalocyanine, 11,531(2007), https://doi.org/10.1142/S108842460700062X

12. Mounesh, Pari Malathesh, N.Y.Praveen Kumara, Bhvimane Jilani, C.D. Mruthynjayachari, K.R. Venugopala Reddy, Heliyon, 5(7), E01946(2019), https://doi.org/10.1016/j.heliyon.2019.e01946

13. Mounesh Nayaka, Bhvimane Sanna Jilani, Malatesh Pari, K.R Venugopala Reddy, K.S Lokesh, Microchemical Journal, 147, 755(2019), https://doi.org/10.1016/j.microc.2019.03.090

14. K.R.V. Reddy, M.N.K. Harish, M.H. Fassiulla, Moinuddin Khan, J. Keshavayya, Journal of Fluorine Chemistry, 128, 1019(2007), https://doi.org/10.1016/j.jfluchem.2007.05.001

15. Bhvimane Sanna Jilani, C.D. Mruthyunjayachari, P. Malatesh, Mounesh, T.M. Sharanakumar, K. R. Venugopala Reddy, Sensors \& Actuators: B, Chemical, 301, 127078(2019), https://doi.org/10.1016/j.snb.2019.127078

16. S. Nagel, M. Lener, C. Keil, R. Gerdes, L. Lukasz, S.M. Gorun. The journal of Physical Chemistry $C, \mathbf{1 1 5}, 8779$ (2011), https://doi.org/10.1021/jp2010748

17. F. Yang, S.R. Forrest, ACS nano, 2, 1022 (2008).

18. S.R. Forrest, Chemical Reviews, 97, 1793(1997), https://doi.org/10.1021/cr941014o

19. C.C. Lenzoff, A.B.P. Lever (Eds.), Phthalocyanine: Properties and Applications, Vol.3, VCH Publisher, New York (1993). 
RASĀYAN J. Chem.

Vol. 14 | No. 3 |1761-1772 | July - September | 2021

20. C.C. Lenzoff, A.B.P. Lever (Eds.), Phthalocyanine: Properties and Applications, Vol.4, VCH Publisher, New York (1996).

21. G. De La Torre, P.Vazquez, F. Agullo-Lopez, T. Torres, Journal of Material Chemistry, 8, 1671 (1998).

22. Mounesh, K.R. Venugopala Reddy, Microchemical Journal, 160, 105610(2021), https://doi.org/10.1016/j.microc.2020.105610

23. R.R. Allison, C.H. Sibada Photodiagn, Photodiagnosis Photodyn Ther, 7(2), 61, (2010).

24. Yilin Tong, Dapeng Li, Jun Huang, Kun Li, Liyun Ding, Tianxia Wang, Jingjing Gong, Journal of Wuhan University of Technology-Mater. Sci. Ed., 29, 567(2014), https://doi.org/10.1007/s11595-014$\underline{0958-8}$

25. E.J. Denisov, I.B Atanas, pp. 448-500, CRC Press, Taylor and Francis(2005).

26. M.S Dieckmann, K.A Gray, Water Research, 30, 1169(1996), https://doi.org/10.1016/0043$\underline{1354(95) 00240-5}$

27. M. H. Moinuddin Khan, Fasiulla, J. Keshavayya and K. R. Venugopala Reddy, Russian Journal of Inorganic Chemistry, 53(1), 66 (2009), https://doi.org/10.1080/17518250903042414

28. Mounesh, T.M. Sharanakumar, N.Y. Praveen Kumar, K.R. Venugopala Reddy, Analytical Chemistry Letters, 10 (5) (2020), https://doi.org/10.1080/22297928.2020.1857835

29. Mounesh, K.R. Venugopala Reddy, Analytical Chimca Acta, 1108, 98(2020), https://doi.org/10.1016/j.aca.2020.02.057

30. T.M. Sharanakumar, Mounesh, N.Y. Praveen Kumar, K.R. Venugopala Reddy, Suresh, Rasayan Journal of Chemistry, 13(4), 2133(2020), http://dx.doi.org/10.31788/RJC.2020.1345876

31. Mounesh, K.R. Venugopala Reddy, Analytical Chemistry Letters, 10(1), 33(2020), https://doi.org/10.1080/22297928.2020.1745683

32. Mounesh, K.R. Venugopala Reddy, New Journal of Chemistry, 44(8), 3330(2020), https://doi.org/10.1039/C9NJ05807A

33. Mounesh, K.R. Venugopala Reddy, Analytical Chimca Acta, 1108, 98(2020), https://doi.org/10.1016/j.aca.2020.02.057

34. Mounesh, B.S. Jilani, P. Malatesh, K.R. Venugopala Reddy, K.S. Lokesh, Microchemical Journal, 147, 755(2019), https://doi.org/10.1016/j.microc.2019.03.090

35. N.Y. Praveen Kumar, Mounesh, T.M. Sharan Kumar, K.R. Venugopal Reddy, Sangappa K. Ganiger, Asian Journal of Chemistry, 32(11), 2722(2020), http://doi.org/10.14233/ajchem.2020.22803

36. V.N. Nemykin, V.Ya. Chernii, S.V. Volkov, N.I. Bundina, O.L. Kaliya, V.D. Li, E.A. Lukyanets, Journal Porphyrins Phthalocyanines, 3(2), 87(1999), https://doi.org/10.1002/(SICI)10991409(199902)3:2<87::AID-JPP108>3.0.CO;2-G

37. N. Sehlotho, T. Nyokong, Journal of Molecular Catalysis A: Chemical, 219, 201(2004), https://doi.org/10.1016/j.molcata.2004.05.010

38. M.H. Lim, S.W. Jin, Y.J. Lee, G.J. Jhon, W. Nam, C. Kim, Bulletine of Korean Chemical Society, 22, 93(2001).

39. E.T. Saka, D. Çakır, Z. Bıyıklıglu, H. Kantekin, Dyes and Pigments. 98, 255(2013), https://doi.org/10.1016/j.dyepig.2013.02.021

40. M. Salavati-Niasari, P. Salemi, F. Davar, Journal of Molecular Catalysis A: Chemical, 238, 215(2005), https://doi.org/10.1016/j.molcata.2005.05.026

41. C. Pratap, K. Shigeru, K. Toshinori, S. Shigeo, Polyhedron, 28, 370 (2009).

42. Mounesh, T.M Sharanakumar, N.Y Praveenkumar, K.R Venugopal Reddy, K. Chandrakala, L Arunkumar, C.C Vidyasagar, RSC Advances, 11, 16736(2021), https://doi.org/10.1039/d1ra01815a

43. Mounesh, N.Y Praveen Kumar, T.M Sharanakumar, K.R Venugopal Reddy, Electrochemical Science Advances, 27(11), 16736(2021), https://doi.org/10.1002/elsa.202100006

[RJC-6386/2021] 